\title{
NEW CONDENSATION PARTICLE COUNTER UF-02
}

\author{
K. Plauškaitè ${ }^{\mathrm{a}}$, G. Mordas ${ }^{\mathrm{a}, \mathrm{b}}$, J. Andriejauskienè ${ }^{\mathrm{a}}$, and V. Ulevičius ${ }^{\mathrm{a}}$ \\ ${ }^{a}$ Institute of Physics, Savanoriu 231, LT-02300 Vilnius, Lithuania \\ E-mail: ulevicv@ktl.mii.lt \\ ${ }^{\mathrm{b}}$ Department of Physical Sciences, University of Helsinki, P.O. Box 64, FI-00014 Helsinki, Finland
}

Received 1 September 2006

\begin{abstract}
A newly developed condensation particle counter UF-02 was approbated and tested. The investigations of the measured concentration range have shown that the condensation particle counter UF-02 can be used for measuring the particle number concentration from 0.002 to $100000 \mathrm{~cm}^{-3}$, and the determined cut-off size was $4 \mathrm{~nm}$. Three newly developed condensation particle counters (CPCs) UF-02 were tested at the SMEAR I station in Värriö (Lapland, Finland). The studied period covers 26 April and 12 May 2003. These CPCs were used for measurement of the aerosol particle number concentration in the atmospheric boundary layer at the SMEAR I station. Two instruments were set into action with the cut-off size of $4.5 \mathrm{~nm}$ and one with $10 \mathrm{~nm}$. The data of the particle number concentration variability were collected. The air mass backward trajectories were used to estimate the prehistory of the air masses. Moreover, trace gas $\left(\mathrm{O}_{3}, \mathrm{NO}_{x}\right.$, and $\left.\mathrm{SO}_{2}\right)$ concentrations were analysed. During these studies the calibration and inter-comparison of instruments were also performed. The information about new characteristics of the instruments was obtained.

Keywords: condensation particle counter (CPC), nucleation, aerosol particles, air mass backward trajectories, meteorological parameters
\end{abstract}

PACS: 92.20.Bk, 92.60.Mt, 92.10.Lq

\section{Introduction}

Aerosols are now recognized to play the main role in such diverse environmental problems as respiratory diseases, climate change, visibility impairment and eutrophication of remote areas [1-3]. Aerosols are also suitable medium in which heterogeneous reactions of gaseous trace constituents occur [4-6]. The sources of each of the major chemical constituents of aerosols must be known and their role in atmospheric processes must be elucidated in order to regulate and reduce their detrimental effects [7]. There are indications that most of the mass in the fine aerosols (particle diameter $D_{\mathrm{p}}<$ $2.5 \mu \mathrm{m}$ ) is secondary, i. e., they are not directly emitted, but formed from gaseous precursors in the atmosphere [8-10]. The absence of reliable data of aerosol measurements prevents understanding of the formation of these secondary aerosols and evaluation of their treatment in chemical transport models, and therefore, in this sense, aerosol science is at a level at which the measurement of most gaseous pollutants has been a decade ago [11]. However, legislation will soon be needed to control the sources and contributions of the major individual aerosol components to the total mass in order to develop efficient abatement strategies for preventing climate change.

The production of new particles in the atmosphere has received a growing experimental interest recently [11]. The observations have shown frequent and abundant formation events of new aerosol particles in the springtime at the SMEAR I station [12]. The absence of reliable aerosol instrumentation restricts the understanding of the formation of secondary aerosols and evaluation of their behaviour in chemical transport and climate models. The condensation particle counters (CPCs) are used for measuring the number concentration of ultra fine particles, which are smaller than could be detected by optical methods [13,14]. The operation principle of the CPC involves three processes: supersaturation of the working fluids, growth of the particles due to condensation of the supersaturated vapours, and optical detection of the particles after growth. The CPCs can be classified according to the technique that is used in creating supersaturation. Three main methods have been currently introduced: adiabatic expansion of an aerosol-vapour mixture [15], conductive cooling [13,16], and mixing of cool and warm saturated air [17-19]. The design of the CPC determines the performance characteristics of the 


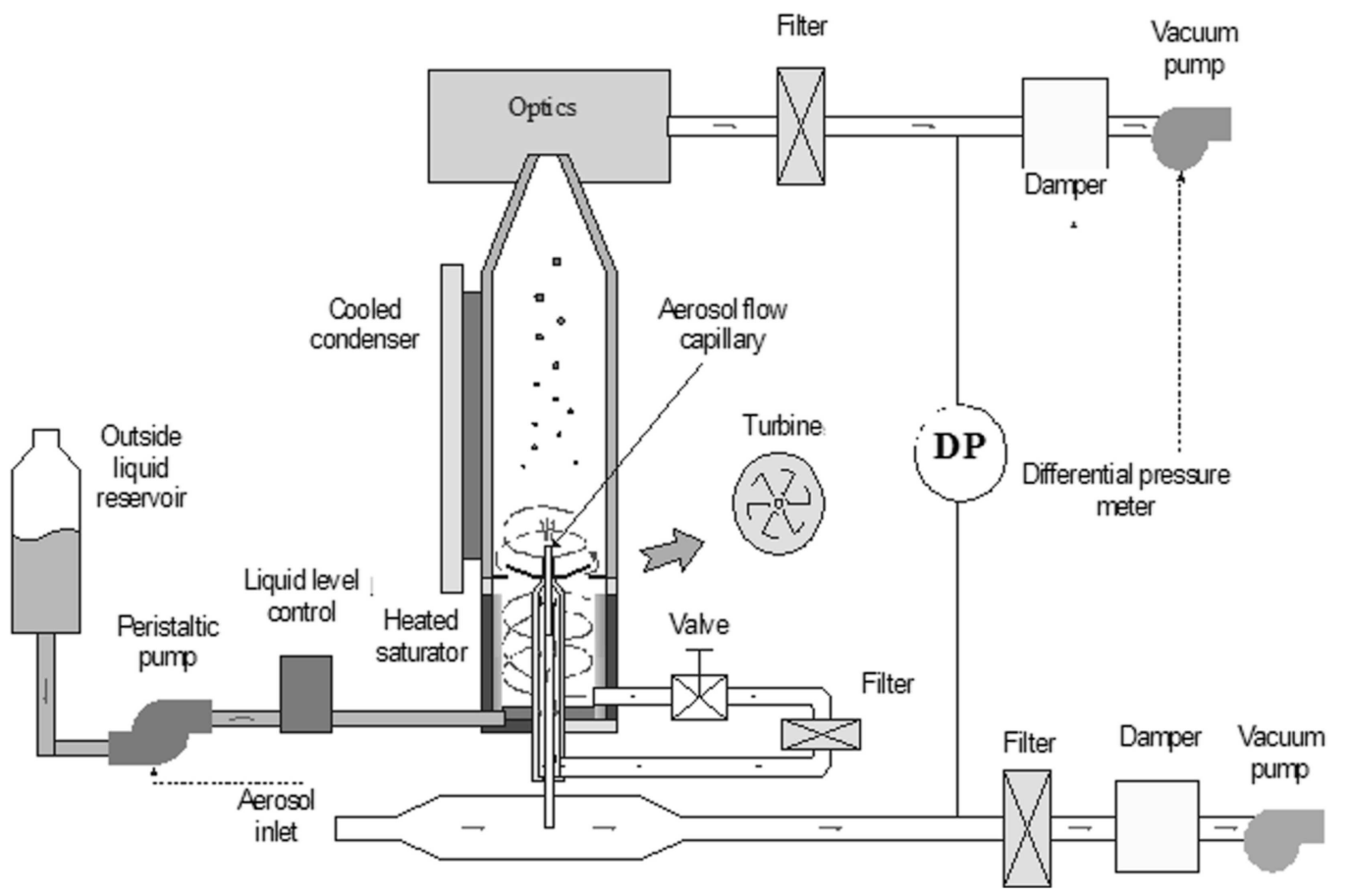

Fig. 1. A schematic illustration of the continuous flow condensation particle counter UF-02.

device. The general characteristics of the CPCs are the particle detection efficiency as a function of the particle size and the highest measured particle number concentration. However, traditional CPC designs have slow detector responses, fluctuations of supersaturation and cut-off size due to turbulent mixing. Another problem with traditional CPCs is that flow recirculations are created in these systems.

\section{Instrument design}

Detection and analysis of aerosols using a condensation particle counter, also called a condensation nucleus counter (CNC), are well known. The CPC is also used as the primary detection means for obtaining particle size distributions, for example, in the scanning mobility particle sizers. The condensation particle counter detects particles by condensing vapour on the particles to grow them to a large enough size to be counted optically. This measurement involves four steps:

1. the production of sufficient quantities of vapour;

2. creation of supersaturation necessary to activate the particle;

3. maintaining of the particles in the supersaturated state long enough to grow to a detectable size;

4. detection of the grown particles.
The sensitivity of a particle counter is defined as the particle size at which $50 \%$ of the particles are detected. In a CPC, the aerosol flow is first saturated with vapour and subsequently cooled to induce supersaturation conditions. For a given saturation level, the vapour can condense onto particles only if they are large enough. The minimum size of particles capable of acting as a condensation nucleus is called the Kelvin diameter. The relationship between the supersaturation rate and the Kelvin diameter $\left(d_{\mathrm{p}}\right)$ can be expressed as

$$
\frac{p_{\mathrm{d}}}{p_{s}}=\delta m_{\mathrm{f}} \exp \left(\frac{4 v \gamma}{R T d_{\mathrm{p}}}\right)
$$

where $p_{\mathrm{d}}$ is the saturation vapour pressure on the droplet surface, $p_{s}$ is the saturation vapour pressure, $\delta$ is the activity coefficient, $m_{\mathrm{f}}$ is the mole fraction of the solute, $\gamma$ is the surface tension, $v$ is the molar volume of the liquid, $R$ is the gas constant, and $T$ is the absolute gas temperature in $\mathrm{K}$ [20]. Equation is derived for vapour condensed on liquid droplets of the same material or on insoluble particles with surface wettable for the working fluid.

There are two basic types of existing CNCs: mixing and cooling ones. The cooling type CNCs reach supersaturation by cooling a previously saturated particlecontaining sample stream. For a mixing type CNCs, supersaturation is determined by the difference of the incoming sample flow and the growth chamber temperatures. 
While some particles immediately exit the mixing region and enter the detector, other particles continue to circulate inside the CPC and randomly exit at some later time, leading to an exponentially decaying distribution of delay times between the particle entrance into $\mathrm{CPC}$ and its detection. Thus, application of such type of CPCs is impractical for obtaining fine particle size distributions.

A newly developed condensation particle counter UF-02 [14] was approbated and tested. The scheme of the CPC model UF-02 is shown in Fig. 1. Inside a saturator block, working fluid ( $n$-butanol) is evaporated from a liquid pool to the passing air flow. The liquid level within the saturator is maintained with a peristaltic pump, which transfers $n$-butanol from an outside reservoir on demand. When the counter is switched off, the pump removes all the butanol from the pool to the reservoir. This protects the optics from flooding with working fluid, e.g., during the relocation of the UF-02 counter.

The high carrier inlet flow of the CPC is $1929 \mathrm{~cm}^{3} / \mathrm{min}$. From the carrier flow, the aerosol flow $\left(274 \mathrm{~cm}^{3} / \mathrm{min}\right)$ is extracted with the capillary tube. Furthermore, the aerosol flow is divided into two flows, one (sheath) flow passing through a high performance filter and a saturator block $\left(242 \mathrm{~cm}^{3} / \mathrm{min}\right)$ and the other (aerosol sample flow) directly to a growth tube $\left(32 \mathrm{~cm}^{3} / \mathrm{min}\right)$. The sheath flow is drawn through a heater where it becomes saturated with vapour. The working liquid is at the bottom of the cylindrical saturator. A liquid level sensor controls the amount of the liquid inside the saturator. The top part of the saturator is connected with the condenser through a special plastic tube. The bottom part of the condenser is cylindrical and the top part is conical. Both parts are cooled $\left(10.45 \pm 0.08^{\circ} \mathrm{C}\right)$ thermoelectrically. The aerosol sample flow enters the cleaned vapour-sheath flow near the inlet of the condenser at its centreline and the saturated sheath air rotates around the aerosol flow. A short, heated section at this juncture allows vapour to diffuse into the aerosol before entering the cooled condenser. As the aerosol sample flow is confined near the centreline of the condenser, it experiences high supersaturation and negligible losses to the wall. For better mixing of the cold aerosol flow and the hot saturated air the turbine is used. It is between the plastic tube and the bottom part of the condenser. The turbine is a slender disk with special formed wings. Thus, the mixing of hot and cold flows and cooling of the condenser create high supersaturation and the particles grow into droplets, which can be detected by optical methods.

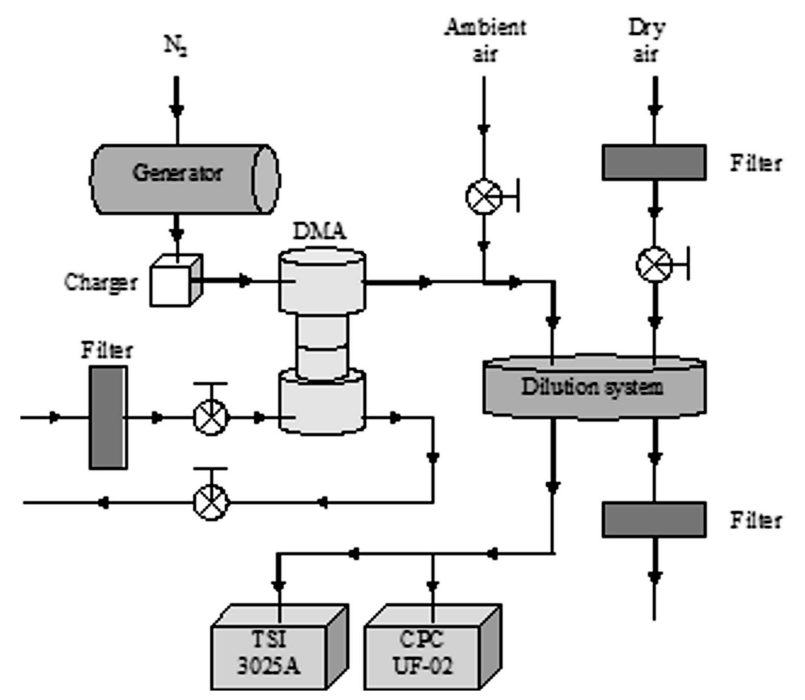

Fig. 2. Calibration system of the condensation particle counter UF-02.

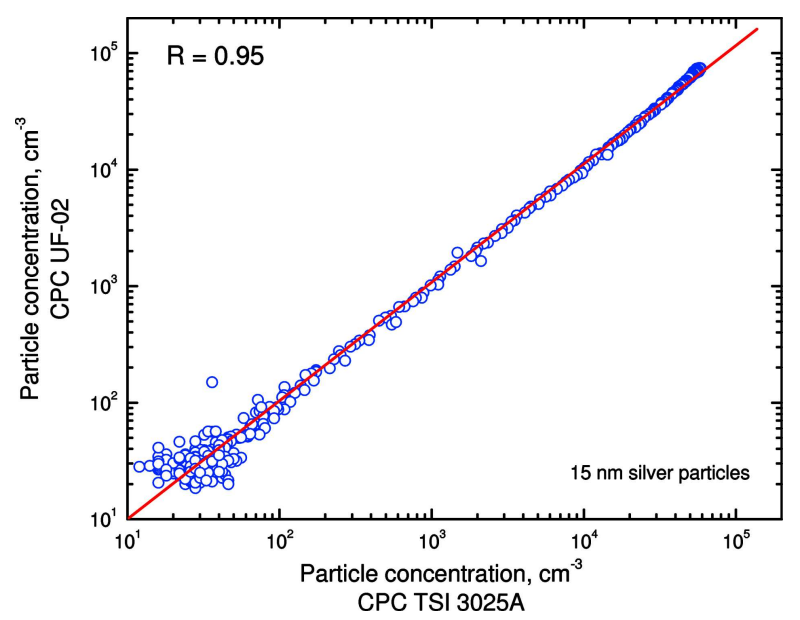

Fig. 3. Correlation of aerosol particle concentrations measured with the TSI $3025 \mathrm{~A}$ and UF-02 condensation particle counters.

The exit nozzle of the top part of the condenser causes the droplets to accelerate and pass through a measurement volume in the optical system. The particle number concentration is calculated using the lifetime counting method. Internal optics focuses the laser light to a thin ribbon just above the aerosol focusing nozzle. Droplets are counted individually with the concentrations up to $10^{5}$ particles per cubic centimetre as they scatter light onto a photomultiplier. The continuous flow is cleaned by a filter (the fall of pressure is low) and controlled volumetrically.

Particles are carried upward the condenser to the optics through the saturated air swirl created by the turbine. The saturated air stream through the turbine contacts tangentially with the inner surface of the chamber. Thus, a weak vortex is produced in the space above the turbine. The swirl velocity increases towards the centre 


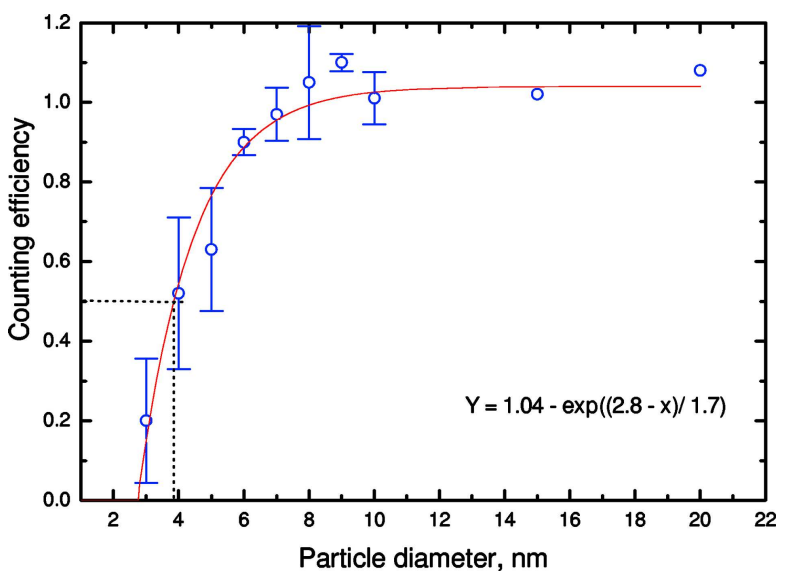

Fig. 4. Counting efficiency of silver particles measured with the condensation particle counter UF-02.

due to conservation of the flow angular momentum creating uniform supersaturation in the central part of the chamber. This inward motion of the swirl reduces particle losses to the inner surfaces of the supersaturation chamber and allow reaching supersaturation very close to the homogeneous nucleation limit.

\section{Instrument calibration}

Experimental set-up was made to determine the particle counting efficiency and the concentration range of the condensation particle counter UF-02 (Fig. 2). For this purpose, silver particles were generated with the Carbalite Furnaces generator. The particles were charged $\left({ }^{241} \mathrm{Am}\right.$ source $)$ and size-segregated with a differential mobility analyzer (DMA). The sample was diluted in both the counting efficiency and concentration range experiments. A diluted monodisperse aerosol sample was transferred to the CPC UF-02 and a reference condensation particle counter TSI 3025A.

The minimum detectable concentration is determined by false background counts in the optics. For these investigations, a HEPA filter was connected with the inlet of the CPC UF-02. The measurements of concentrations were made during one hour. The average number concentration during the measurement period was calculated. The results show that the false particle number concentration background was only $0.002 \mathrm{~cm}^{-3}$, when the temperature difference between the saturator and the condenser was set at $32.5^{\circ} \mathrm{C}$. The existence of this background can be explained by the particle production due to homogeneous or ion-induced nucleation inside the CPC or by the noise of the electronics. However, as recently shown by Kulmala [21], homogeneous nucleation under these conditions is improbable. The maximum measured number concentra- tion was investigated by comparing the number concentration measured with the UF-02 to that of the reference CPC TSI 3025A. The experiments were performed using monodisperse aerosol with a particle diameter of $15 \mathrm{~nm}$ (Fig. 3). As the results have shown, application of a new counting method allows registering aerosol particle concentration up to $100000 \mathrm{~cm}^{-3}$. The investigation was impossible at higher particle concentrations because instruments used in the experiment are able to determine particle concentrations only up to $100000 \mathrm{~cm}^{-3}$. When the concentration of aerosol particles is higher than $10000 \mathrm{~cm}^{-3}$, the condensation particle counter TSI 3025A detects a lower particle concentration than the CPC UF-02. This is related to the aerosol particle detection methods. In the concentration range from 0 to $10000 \mathrm{~cm}^{-3}$ the CPC TSI $3025 \mathrm{~A}$ uses the single particle counting method and from 10000 to $100000 \mathrm{~cm}^{-3}$ the concentration is detected by the light absorption method. The UF-02 condensation particle counter in the whole working range uses a single particle counting method for determination of the particle concentration. The investigations of the measured concentration range showed that the CPC UF-02 can be used to measure the particle number concentration from 0.002 to $100000 \mathrm{~cm}^{-3}$.

One of the main characteristics of a CPC is the particle counting efficiency as a function of the particle diameter (Fig. 4). To determine the counting efficiency of the CPC UF-02 the silver particles of 1-30 nm size were generated. The counting efficiency reached a value of 1 at larger particle sizes and it was smaller than 0.9 for particles smaller than approximately $5 \mathrm{~nm}$. The counting efficiency decreased rapidly and was about 0.18 for $3 \mathrm{~nm}$ particles, i. e., UF- 02 registered only $18 \%$ of $3 \mathrm{~nm}$ particles that passed into the condensation particle counter. All other particles did not grow in the condenser or they were lost due to diffusion. The measured counting efficiency curve was steep providing a well-defined smallest observable size. The determined cut-off size of the CPC UF-02, i. e., the size when 50\% of particles were counted, was $4 \mathrm{~nm}$.

\section{Aerosol measurements}

Three newly developed CPCs UF-02 [14] were tested at the SMEAR I station in Värriö (Lapland, Finland). These condensation particle counters were used for measurements of the aerosol particle number concentration in the atmospheric boundary layer. Two instruments were set into action with the cut-off size of 


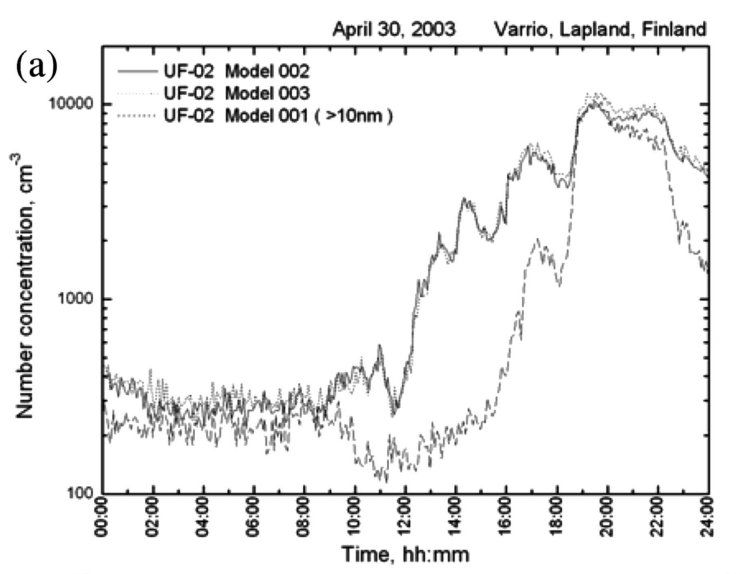

(b)

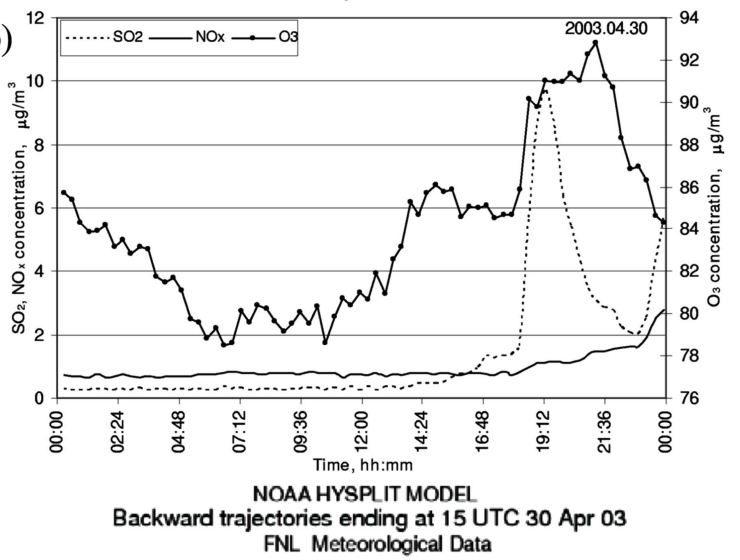

(c)

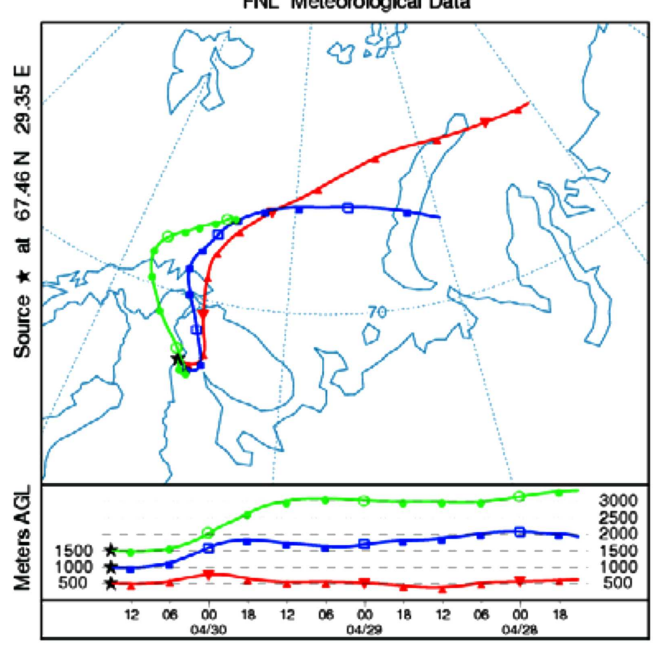

Fig. 5. (a) Time evolution of aerosol particle size concentration, (b) $\mathrm{SO}_{2}, \mathrm{NO}_{x}$, and $\mathrm{O}_{3}$ concentrations, and (c) air mass backward trajectories at the SMEAR I station (Värriö, Finland) on 30 April 2003.

$4.5 \mathrm{~nm}$ and the third one with $10 \mathrm{~nm}$. All three instruments were calibrated with the silver particles before the experiment.

During the LAPBIAT measurement campaign on 26 April - 12 May 2003 the data of the particle number concentration variability were collected as well as calibration and inter-comparison of the instruments were performed. The information about new characteristics
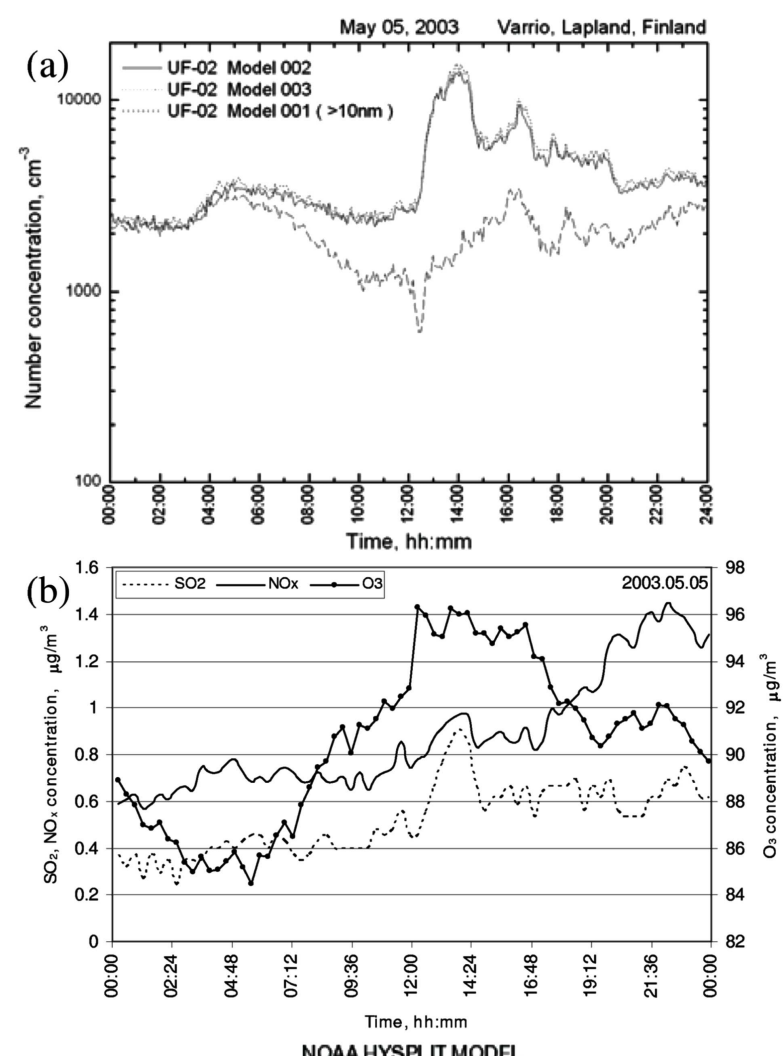

(c)

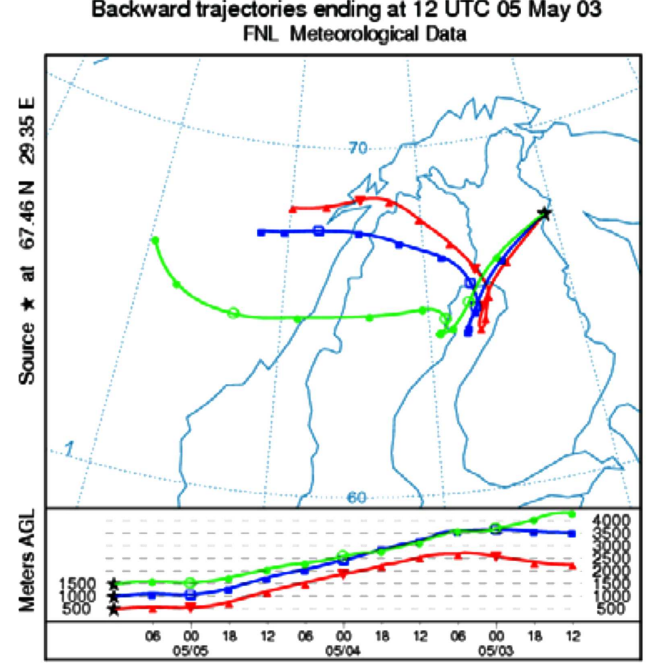

Fig. 6. (a) Time evolution of aerosol particle size concentration, (b) $\mathrm{SO}_{2}, \mathrm{NO}_{x}$, and $\mathrm{O}_{3}$ concentrations, and (c) air mass backward trajectories at the SMEAR I station (Värriö, Finland) on 5 May 2003.

of the instruments was obtained. Side-by-side measurements of the total particle concentrations $\left(D_{\mathrm{p}}>\right.$ $4.5 \mathrm{~nm}$ ) with two instruments have shown that the correlation coefficient is high $(R=0.95$, Fig. 3$)$ and indicated that both condensation particle counters reliably measure the total particle number concentration under the subarctic conditions. During the measurement period three nucleation events were observed (Figs. 5(a)7(a)). The formation of new aerosol particles clearly 
correlated with high values of solar radiation. The low relative humidity can be related to nucleation events at the SMEAR I station. No clear relationship between other meteorological factors (temperature, wind speed and direction) and formation of new aerosol particles was observed. The low concentration of preexisting particles is one more condition for the nucleation occurrence.

At the SMEAR I station the concentrations of sulphur dioxide, nitrogen oxides, and ozone were measured for the entire period. As can be seen from Figs. 5(b) and 6(b), the increase in $\mathrm{SO}_{2}$ concentrations can be related to the increase in the total concentration of particles the diameter $D_{\mathrm{p}}$ of which is greater than $10 \mathrm{~nm}$, and at the same time the nucleation process (the formation of small nanometrical particles, $4<D_{\mathrm{p}}<$ $10 \mathrm{~nm}$ ) has stopped and the total concentration of particles with $D_{\mathrm{p}}>4 \mathrm{~nm}$ has been influenced only by the particles the diameter of which is larger than $10 \mathrm{~nm}$. It means that there is an inverse correlation between nucleation events and $\mathrm{SO}_{2}$ concentration. Thus, low concentration of $\mathrm{SO}_{2}$ can be one of the conditions, but not necessary, for nucleation to occur (Fig. 7(b)). The impact of changes in the $\mathrm{NO}_{x}$ concentration on the formation of new aerosol particles seems to be not so very important, but similar to the influence of the $\mathrm{SO}_{2}$ concentration (Figs. 5(b)-7(b)). From the same figures it can be seen that formation of new aerosol particles is related to higher concentrations of $\mathrm{O}_{3}$, which seems to be another condition for nucleation of new particles.

To estimate the prehistory of air masses for the measurement period the series of 72-hour air mass backward trajectories were calculated using the Hybrid Single-Particle Lagrangian Integrated Trajectories model Version 4 (HY-SPLIT) [22]. The nucleation events were accompanied by the clean air masses arriving from northern directions (Figs. 5(c), 7(c)), except on 5 May when air masses came from southwest (Fig. 6(c)), but the concentrations of $\mathrm{SO}_{2}$ and $\mathrm{NO}_{x}$ were not very high (Fig. 6(b)).

The described experimental data provide information on the application of a new condensation particle counter in future studies of nucleation processes in the atmosphere.

\section{Summary and conclusions}

The investigations of the measured concentration range have shown that the condensation particle counter UF-02 can be used to measure the particle number concentration from 0.002 to $100000 \mathrm{~cm}^{-3}$, and the de-

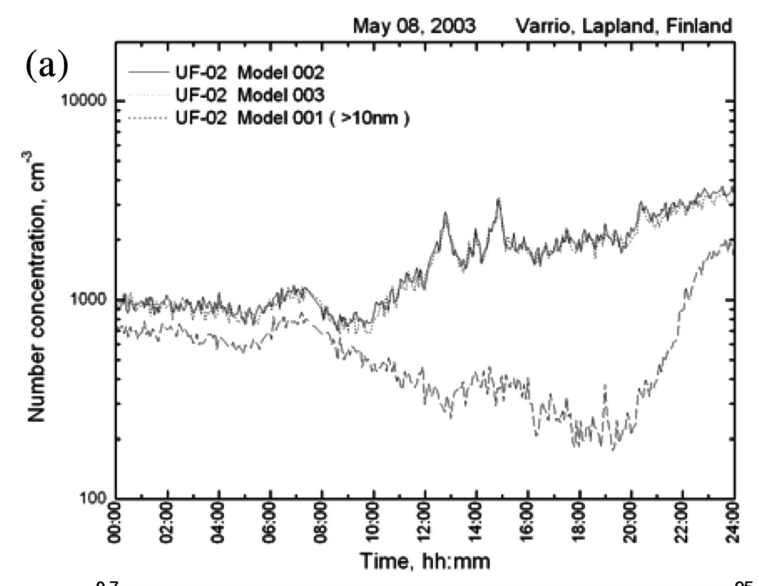

(b)
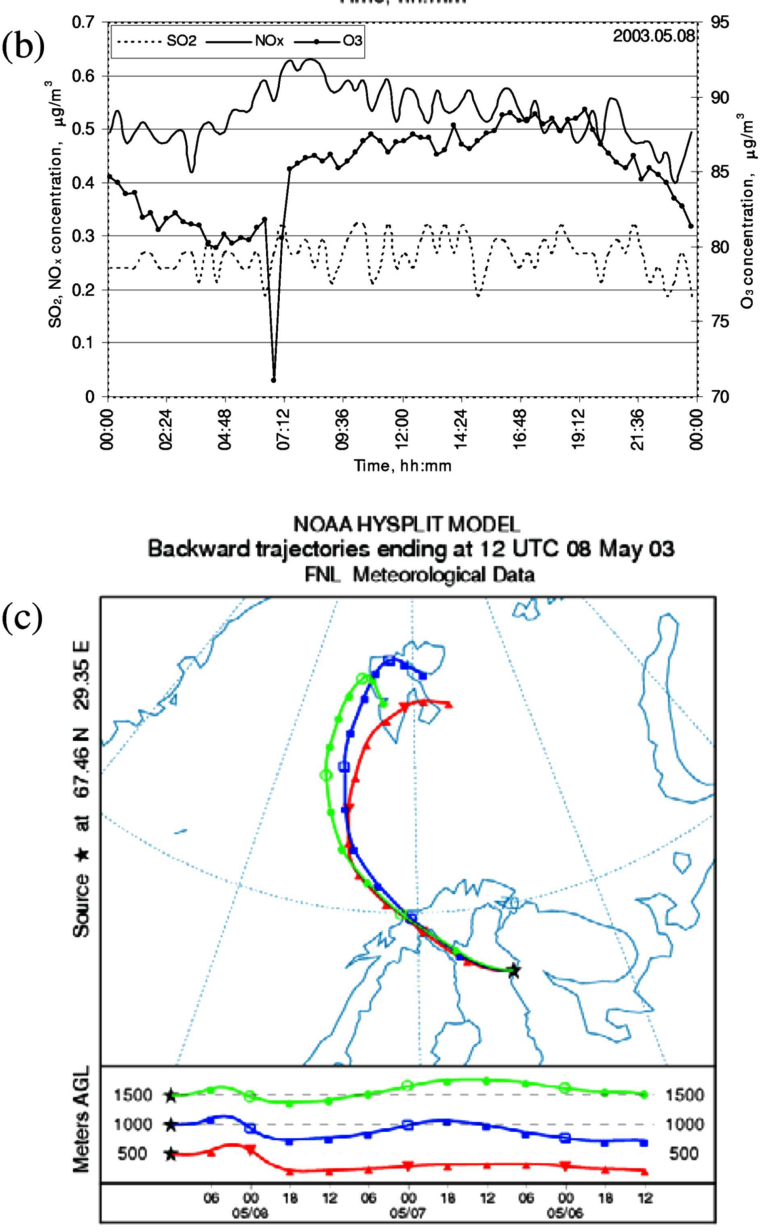

Fig. 7. (a) Time evolution of aerosol particle size concentration, (b) $\mathrm{SO}_{2}, \mathrm{NO}_{x}$, and $\mathrm{O}_{3}$ concentrations, and (c) air mass backward trajectories at the SMEAR I station (Värriö, Finland) on 8 May 2003.

termined cut-off size was $4 \mathrm{~nm}$. Three new CPCs UF-02 were tested at the SMEAR I station in Värriö (Lapland, Finland). All three instruments were calibrated with the silver particles before the experiment and after that were used for the measurements of the aerosol particle number concentration in the atmospheric boundary layer. Two instruments were set 
into action with the cut-off size of $4.5 \mathrm{~nm}$ and one with $10 \mathrm{~nm}$. Side-by-side measurements of the total particle concentrations $\left(D_{\mathrm{p}}>4.5 \mathrm{~nm}\right)$ with two instruments have shown that the correlation coefficient is high $(R=0.95)$ and indicated that both condensation particle counters reliably measure the total particle number concentration under the subarctic conditions.

During the measurement period three nucleation events were observed. The formation of new aerosol particles clearly correlated with high values of solar radiation. Clean air masses with low concentrations of $\mathrm{SO}_{2}$ and $\mathrm{NO}_{x}$ can be related to the nucleation events. Low relative humidity and low concentration of preexisting particles are other conditions for the nucleation occurrence.

The obtained experimental data are valuable sources of information for the application of a new condensation particle counter in the future studies of nucleation processes in the atmosphere.

\section{Acknowledgements}

This research was supported by the Lithuanian State Science and Studies Foundation, FP5 project LAPBIAT, and FP6 project ACCENT.

\section{References}

[1] L. Gradon and A. Podgorski, Kinetics of particle retention in the human respiratory tract, Annals Occupat. Hygiene 35, 249-259 (1991).

[2] B. Altshuler, E.D. Palmes, and N. Nelson, Regional Aerosol Deposition in the Human Respiratory Tract (Pergamon Press, New York, 1997).

[3] G. Buzorius and K. Hämeri, Spatial variation of aerosol number concentration in Helsinki city, Atmos. Environ. 33, 553-565 (1999).

[4] P.M. Korhonen, M. Kulmala, A. Laaksonen, Y. Viisanen, R. McGraw, and J.H. Seinfeld, Ternary nucleation of $\mathrm{H}_{2} \mathrm{SO}_{4}, \mathrm{NH}_{3}$, and $\mathrm{H}_{2} \mathrm{O}$ in the atmosphere, J. Geophys. Res. 104, 26349-26353 (1999).

[5] R.J. Weber, P.H. McMurry, L. Mauldin, D.J. Tanner, F.L. Eisele, F.J. Brechtel, S.M. Kreidenweis, G.L. Kok, R.D. Schillawski, and D. Baumgardner, A study of new particle formation and growth involving biogenic and trace gas species measured during ACE 1, J. Geophys. Res. 103, 16385-16396 (1998).

[6] J.H. Seinfeld and S.N. Pandis, Atmospheric Chemistry and Physics, from Air Pollution to Climate Change (John Wiley \& Sons, Inc., New York., 1998).

[7] P.H. McMurry, A review of atmospheric aerosol measurements, Atmospheric Environment 34, 1959-1999 (2000).
[8] L. Pirjola, M. Kulmala, M. Wilck, A. Bischoff, F. Stratmann, and E. Otto, Effects of aerosol dynamics on the formation of the sulphuric acid aerosols and cloud condensation nuclei, J. Aerosol Sci. 30, 1079-1094 (1999).

[9] M. Kulmala, A. Toivonen, J.M. Mäkelä, and A. Laaksonen, Analysis and growth of the nucleation mode particles observed in Boreal forest, Tellus B 50, 449462 (1998).

[10] M. Kulmala, Atmospheric science: How particles nucleate and grow, Science 302, 1000-1001 (2003).

[11] M. Kulmala, H. Vehkamäki, T. Petäjä, M. Dal Maso, A. Lauri, V.M. Kerminen, W. Birmili, and P.H. McMurry, Formation and growth rates of ultrafine atmospheric particles: A review of observations, J. Aerosol Sci. 35, 143-176 (2004).

[12] M. Vana, M. Noppel, U. Hõrrak, T.M. Ruuskanen, P.P. Aalto, and M. Kulmala, Formation and growth events of atmospheric nanoparticles at Värriö research station during LAPBIAT measurement campaign, in: Abstracts of European Aerosol Conference 2005, ed. W. Maenhaut (Ghent, Belgium, 2005) p. 488.

[13] G.J. Sem, Design and performance characteristics of three continuous-flow condensation particle counters: A summary, Atmos. Res. 62, 267-294 (2002).

[14] V. Ulevičius, M. Kulmala, G. Mordas, V. Matulevičius, V. Grigoraitis, K. Hämeri, and P. Aalto, Method and apparatus for increasing the size of small particles, EU Patent No. EP1702205 (2006).

[15] A.L. Metnieks and L.W. Pollak, Instruction for Use of Photo-electric Condensation Nucleus Counters, Geophys. Bull. No. 16 (School of Cosmic Physics, Dublin Institute for Advanced Studies, 1959).

[16] J.A. Bricard, P. Delattre, G. Madeleine, and M. Pourprix, Detection of ultra-fine particles by means of a continuous flux condensation nuclei counter, in: Fine Particles: Aerosol Generation, Measurement, Sampling, and Analysis, ed. B.Y.H. Liu (Academic Press, New York, 1976) pp. 565-580.

[17] Y. Kousaka, T. Niida, K. Okuyama, and H. Tanaka, Development of a mixing type condensation nucleus counter, J. Aerosol Sci. 13, 231-240 (1982).

[18] R. Mavliev, Turbulent mixing condensation nucleus counter, Atmos. Res. 62, 302-314 (2002).

[19] J. Wang, V.F. McNeill, D.R. Collins, and R.C. Flagan, Fast mixing condensation nucleus counter: Application to rapid scanning differential mobility analyzer measurements, Aerosol Sci. Technol. 36, 678689 (2002).

[20] Y.S. Cheng, Condensation detection and diffusion size separation techniques, in: Aerosol Measurement: Principles, Techniques and Applications, eds. K. Willeke and P.A. Baron (Van Nostrand Reinhold, New York, 1993) pp. 427-451. 
[21] M. Kulmala, K.E.J. Lehtinen, L. Laakso, G. Mordas, and K. Hämeri, On the existence of neutral atmospheric clusters, Boreal Env. Res. 10, 79-87 (2005).
[22] National Oceanic and Atmospheric Administration (NOAA, U.S.) Air Resources Laboratory HYSPLIT model, www.arl.noaa.gov/ready.html.

\title{
NAUJAS KONDENSACINIS DALELIŲ SKAITIKLIS UF-02
}

\author{
K. Plauškaitè ${ }^{\mathrm{a}}$, G. Mordas ${ }^{\mathrm{a}, \mathrm{b}}$, J. Andriejauskienè ${ }^{\mathrm{a}}$, V. Ulevičius ${ }^{\mathrm{a}}$ \\ ${ }^{a}$ Fizikos institutas, Vilnius, Lietuva \\ ${ }^{\mathrm{b}}$ Helsinkio universitetas, Helsinkis, Suomija
}

\section{Santrauka}

Sukurtas naujas kondensacinis dalelių skaitiklis UF-02, galintis matuoti aerozolio dalelių skaitinę koncentraciją nuo 0,002 iki $100000 \mathrm{~cm}^{-3}$, bei ivertintas skaitiklio registravimo efektyvumas. Nustatyta, kad prietaisas $4 \mathrm{~nm}$ sidabro daleles, naudotas kalibravimui, registruoja 50\% efektyvumu. Eksperimentiniams aerozolio dalelių skaitinès koncentracijos matavimams trys naujai sukurti kondensaciniai dalelių skaitikliai UF-02 buvo išbandyti SMEAR I stotyje Värriö (Suomija). Matavimai buvo vykdomi 2003 metų balandžio 26 - gegužès 12 dienomis. Du prietaisai buvo suderinti taip, kad matuotų didesnes nei 4,5 nm skersmens daleles, o trečiasis - didesnes nei $10 \mathrm{~nm}$. Tuo pačiu metu atliekant bendros daleliu $\left(D_{\mathrm{p}}>4,5 \mathrm{~nm}\right)$ koncentracijos matavimus su dviem vienodais instrumentais, gautas aukštas koreliacijos koeficientas $(R=$
$0,95)$ ir nustatyta, kad abu kondensaciniai dalelių skaitikliai patikimai matuoja bendrą skaitinę dalelių koncentraciją subarktinėmis sąlygomis. Skaičiuotos atgalinès oro masiu pernašos trajektorijos, nustatant oro masių priešistorę. Taip pat buvo matuojamos $\mathrm{SO}_{2}$, $\mathrm{NO}_{x}$ ir $\mathrm{O}_{3}$ dujų koncentracijos. Matavimo laikotarpiu buvo užregistruoti trys nukleacijos epizodai. Tyrimai parodè, kad naujų dalelių susidarymas vyko esant didelei saulès radiacijai. Nedidelès $\mathrm{SO}_{2}$, ir $\mathrm{NO}_{x}$ dujų koncentracijos, užregistruotos atslinkus švaraus oro masèms, taip pat gali būti susijusios su nukleacijos vyksmais. Nedidelè dalelių koncentracija prieš nukleacijos epizodą bei maža santykiné drégmė yra vienos iš sąlygų naujų dalelių susidarymui subarktinèmis sąlygomis. Eksperimento metu gauta informacija yra vertinga aprobuojant ir isisavinant sukurtą naują kondensacini dalelių skaitiklį UF-02 nukleacijos procesų atmosferoje tyrimams. 